\title{
SPOLEČENSKÁ ODPOVĚDNOST FIREM A SOCIÁLNÍ PILÍŘ
}

\author{
Renáta Nárožná
}

Klíčová slova:

sociální intergace, Společenská odpovědnost firem, marketingový výzkum

\section{Key words:}

social integration, corporate social responsibility, marketing research

\begin{abstract}
Abstrakt
Sociální integraci lze chápat jako soubor opatření, zaměřených na opětovné začlenění marginalizovaných skupin lidí do sociálního proudu. V České republice je toto komplexní úsilí spojeno výhradně se závazky státu, obcí a činnosti nevládních neziskových organizací. Role soukromého sektoru je v této oblasti spíše okrajová. Nicméně, je zřejmé, že stát, striktním oddělováním charitativní činnosti od ziskových činností, brání v mnoha ohledech v úspěšném procesu sociální integrace, zejména $\mathrm{v}$ oblasti zaměstnanosti a bydlení, které jsou rozhodující pro tento proces. Tento článek se pokouší zhodnotit status quo, popsat současné trendy, naznačující změnu v této oblasti (např. dotační politika Ministerstva pro místní rozvoj a Ministerstvo práce a sociálních věcí České republiky), a navrhnout některé další opatření. Úzce s tímto tématem souvisí také otázka měřitelnosti odpovědnosti soukromého sektoru, která je základním předpokladem zapojení podniků v aktivitách sociální integrace a využití státních dotací, které jsou $\mathrm{k}$ dispozici v této oblasti.
\end{abstract}

\begin{abstract}
Social integration can be understood as a package of measures aimed to reintegrate marginalized groups of people into the social mainstream. In the Czech Republic, this comprehensive effort is associated solely with liabilities of state and municipalities and activities of non-governmental non-profit organizations. The role of private sector has been rather marginal in this area. However, it is obvious that the state, strictly separating beneficent-like efforts from profitable activities, hinders successful process of social integration in many aspects, particularly in the area of employment and housing that are crucial for this process. This article attempts to evaluate the status quo, describe current tendencies indicating a change (e.g. subsidy policy of the Ministry of Regional Development and the Ministry of Labor and Social Affairs of the Czech Republic), and suggest some other measures. Closely related to this topic is also the question of measurability of private sector's responsibility, which is a precondition of engagement of companies in social integration activities and utilization of state subsidies available in this field.
\end{abstract}

\section{Úvod}

V tomto článku jsem se snažila analyzovat společenskou odpovědnost podniků právě v oblasti sociální, konkrétně sociální integrace, což je soubor opatření směřujících $\mathrm{k}$ návratu marginalizovaných skupin obyvatelstva do hlavního společenského proudu.

Soustředit se budu na vztah mezi dvěma oblastmi, a to podnikání a sociální integraci, jejichž blízkost či vzdálenost, propojenost či naopak naprostá diskrétnost sama o sobě vyjadřuje míru společenské odpovědnosti podnikání v určité konkrétní oblasti, ale nejen ji. Vyjadřuje také míru, v jaké stát vytváŕí vhodné podmínky pro soulad mezi ziskovostí a společenskou odpovědností. Nebudu se izolovaně soustředit pouze na společensky odpovědné podnikání, 
nezávislé na podpoře státu, odpovědnosti vyrůstající pouze $\mathrm{z}$ uvědomělosti podnikatele, zaměstnavatele, nájemce bytu apod., nýbrž právě také na podmínky, které pro zapojení prvku sociální odpovědnosti do podnikatelských záměrů vytváŕí stát. Vycházím přitom z premisy, že podnikatelská odpovědnost je ze samotné definice spjatá se ziskovostí, byt' optimalizovanou, a společensky významným jevem pak může být právě natolik, nakolik tato premisa platí.

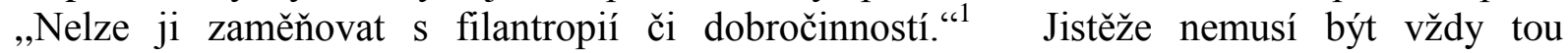
nejekonomičtější variantou, ale musí být volbou, která umožňuje vytvářet zisk. Konečně v citovaném dokumentu se ř́ká: „CSR zůstává primárně dobrovolnou aktivitou. Evropská zkušenost však dokazuje, že stát či vláda mohou šíření tohoto trendu podpořit tím, že vytvoří odpovídající podmínky pro jeho hlubší zakořenění."1 Vytvoření vhodného legislativního rámce může urychlit přijetí některých principů společensky odpovědného chování ze strany firem, obecně však v evropské diskusi převládá názor, že vláda by se neměla koncentrovat výhradně na legislativní opatření, ale měla by se snažit společensky odpovědnému chování napomáhat i jinými cestami. Např́klad tím, že bude zohledňovat hlediska společensky odpovědného chování při zadávání veřejných zakázek a dále pak prostřednictvím informační podpory, velmi vhodná je rovněž podpora prostřednictvím správně nastavené dotační politiky.

\section{Vymezení pojmu CSR (corporate social responsibility)}

Pojetí CSR vymezuje dvěma stěžejními faktory. Jedním je podnikání typu „triple-bottomline business", které předpokládá strategické fungování podniku ve třech oblastech ekonomické, sociální a environmentální (Trnková, 2004).

V CSR jde především o harmonizaci ekonomických dimenzí podnikání se sociálním a ekologickým prostředím, se zohledněním ambivalentního charakteru výsledků (Putnová, 2008).

\section{- Ekonomická rovina CSR}

Principy dobrého řízení firmy, odmítnutí korupce, transparentnost, dodavatelsko-odběratelské vztahy, vztahy se zákazníky, kvalita a bezpečnost produktů či služeb.

\section{- Sociální rovina CSR}

zdraví a bezpečnost zaměstnanců

rozvoj lidského kapitálu, vzdělávání zaměstnanců

vyváženost pracovního a osobního života zaměstnanců (work-life balance)

rovné př́ležitosti (pro ženy, muže a obecně znevýhodněné skupiny)

$\square$ rozmanitost na pracovišti (etnické minority, handicapovaní a starší lidé)

zajištění rekvalifikace propouštěných zaměstnanců pro jejich další uplatnění

$\square$ dodržování pracovních standardů, zákaz dětské práce

$\square$ firemní filantropie (dárcovství, firemní dobrovolnictví a další)

\section{- Environmentální rovina CSR}

Ekologická výroba, produkty a služby (standardy řady EMAS a ISO), ochrana př́rodních zdrojů (spotřeba vody, energií), investice do ekologických technologií, ekologická firemní politika (recyklace, používání ekologických produktů), zmenšování negativních dopadů na

\footnotetext{
${ }^{1}$ Srov. SPOLEČENSKÁ ODPOVĚDNOST FIREM kompletní průvodce tématem a závěry výzkumu v ČR, http://www.blf.cz/csr/cz/vyzkum.pdf, str. 7

${ }^{1}$ Srov. SPOLEČENSKÁ ODPOVĚDNOST FIREM kompletní průvodce tématem a závěry výzkumu v ČR, http://www.blf.cz/csr/cz/vyzkum.pdf, str. 8
} 
životní prostředí, šetrné užívání energie/vody, odpadové hospodaření, environmentální management (Trnková, 2004).

\section{Pojem sociální integrace}

Měla bych však ještě přiblížit pojem sociální integrace, aby bylo jasné, co přesně jím myslím. Jedná se o soubor aktivit vedoucích $\mathrm{k}$ návratu marginalizovaných skupin zpět do hlavního společenského proudu. V tomto ohledu může být řeč o zdravotně handicapovaných, seniorech či dalších skupinách. Já však budu tento výraz spojovat převážně s obyvateli ze sociálně vyloučených lokalit a znevýhodněnými lidmi na trhu práce, protože si myslím, že právě na tyto skupiny obyvatel se soustředí velmi malé procento firem, které se chovají společensky odpovědně v oné sociální oblasti. Má-li být pojem sociálního začleňování či integrace užíván smysluplně, musí se pojit s komplexem podpůrných opatření, která postihují všechny důležité stránky života. Obvykle se hovoří o čtyřech oblastech, kam by měla pomoc směřovat. Hovoří se o podpoře vzdělávání dětí, o pomoci při návratu na trh práce-rekvalifikace atp., o asistenci při zajištění adekvátního bydlení a o pomoci s řešením patologických jevů, které život $\mathrm{v}$ chudinských ghettech generuje. Toto dělení není zcela výstižné a každého napadne, že by tam mělo být ještě zdraví a celá řada dalších věcí. Ale vyjěme třeba odtud. $Z$ hlediska státu jsou podpůrné integrační aktivity doménou samosprávných celků, rozumí se obcí a kraj, jejich př́spěvkových organizací a dalších nestátních neziskových organizací. K těmto subjektům směřuje podstatná část dotačních titulů, které se na různé oblasti sociální integrace vztahují.

Když si odmyslím jiné problémy, které poskytování služeb provázejí, mohu říct, že je to dostačující pro oblast vytváření rovných podmínek ve vzdělání a v oblasti poskytování sociálních služeb podle zákona 108/2006 o sociálních službách, které obecně řečeno „zajišt’ují pomoc a podporu osobám za účelem sociálního začlenění nebo prevence sociálního vyloučení“. ${ }^{2}$

Podpora garantovaná sociálními službami tak je schopna vyrovnat širokou škálu zdravotních a sociálních handicapů. Tato vazba aktivit směřujících $\mathrm{k}$ sociální integraci na samosprávné celky a neziskové organizace je však omezující v oblasti zaměstnávání a bydlení, které lze přitom chápat jako zcela klíčové. Je třeba říct, že konkrétně uplatnění na trhu práce chápou mnozí jako základní předpoklad a nutný první krok všech snah otevř́it marginalizovaným skupinám obyvatel cestu zpět do společnosti. Ale lze úspěšně zprostředkovat návrat lidí se sociálním znevýhodněním na trh práce bez širšího zájmu soukromých zaměstnavatelů?

Situace v oblasti podpory znevýhodněných obyvatel při vstupu či návratu na trh práce je přitom do určité míry paradoxní, je-li chápána izolovaně. Operační program Lidské zdroje a zaměstnanost věnuje této cílové skupině či cílovým skupinám prioritní osu 3, která je základem pro financování souboru aktivit na tomto poli. Pro všechny podporované aktivity, sociální služby a zejména další podporované činnosti platí, že by měly přímo nebo zprostředkovaně vést $\mathrm{k}$ návratu podpořených osob na trh práce. U některých podporovaných aktivit je tato souvislost jen velmi těžko rekonstruovatelná, některé jiné činnosti jsou přitom na podporu zaměstnanosti či zaměstnatelnosti marginalizovaných skupin zaměřené velmi explicitně. Najdeme zde programy osvojování profesních dovedností, programy pracovní a sociální rehabilitace. Což jsou sice velmi důležité podpůrné prostředky při návratu na trh práce, ale není to práce samotná. Vytváření podporovaných pracovních míst je $\mathrm{v}$ rámci této osy, která je vyčleněna pro podporu sociální integrace, věnován velmi malý prostor s jasnými

\footnotetext{
${ }^{2}$ Zákon 108/2006, § 3., https://sluzbyprevence.mpsv.cz/dok/zakon-108_2006.pdf
} 
omezeními. Jedním z nich je např́íklad omezení spektra žadatelů v témže smyslu, jak jsem o tom hovořila výše. Jedná se o dotační titul pro obce a neziskové organizace. Typičtí zaměstnavatelé mající zásadní význam pro rozvoj regionů, mám na mysli malé a střední podnikatele, jsou z tohoto spektra vyloučení. Výjimku tvoří jediná výzva s názvem „investiční podpora sociální ekonomiky“, kde mohou o finanční podporu žádat osoby samostatně výdělečně činné a právnické osoby typické pro podnikatelskou činnost. Tato výzva má svoje limity jednak v omezeném množství prostředků, které lze čerpat, jednak ve značné administrativní náročnosti a př́sně nastavené udržitelnosti, vinou kterých tento zdroj finanční podpory využívá zatím jen velmi málo podnikatelů.

Lze tedy shrnout, že dotační politika prozatím vytváŕí poměrně malý prostor pro zapojení podnikatelských subjektů do procesu sociální integrace marginalizovaných skupin obyvatel. Nejedná se přitom jen o dotace. Myslím, že logická výstavba implementační struktury operačního programu neodráží jen přísná kritéria evropské komise, ale také jen pomalu se proměňující postoj společnosti $\mathrm{k}$ lidem $\mathrm{z}$ různých důvodů žijících na její periferii. Jsme dostatečně sociální, abychom věnovali přiměřené množství prostředků na jejich podporu a návrat do hlavního společenského proudu, ale ne ještě dost otevření či uvědomělí, abychom tuto podporu poskytovali přímo v tomto hlavním proudu. Podobný trend by bylo snadné ukázat např̀. na nastavení legislativního rámce.

Konkrétně tím myslím, že proces sociální integrace a jmenovitě integrace na trh práce, který začíná $\mathrm{v}$ otevřené náruči pomáhající organizace, $\mathrm{v}$ ní také díky nedostatku zapojení běžných zaměstnavatelů často končí. $Z$ této pozice lze také jistě polemizovat s pojmem „sociální firma“ či „sociální ekonomika.“ Je skutečně na místě odpovědnost za znevýhodněné občany situovat do speciálního druhu firem nebo by se mělo jednat o otázku odpovědnosti všech firem, přesněji řečeno o prŕležitost pro všechny uplatnit společenskou odpovědnost podnikání $\mathrm{v}$ této oblasti? Jsem si vědoma jistého zjednodušení, ale jedná se mi pouze o nastínění úhlu pohledu.

Cílem mého příspěvku je vzájemně přiblížit alespoň teoreticky pojem společenské odpovědnosti firem a pojem sociální integrace. Podívejme se proto na věc také z opačné strany: Společenská odpovědnost firem má na základě širokého odborného konsenzu tři pilíře: ekonomický, sociální a enviromentální. V rámci oblasti označované jako sociální uvádí Nový průvodce CSR také koncept „,sociální integrace“. 3

Konečně Vladimír Špidla ještě jako komisař pro sociální věci v Evropské komisi říká při př́ležitosti vzniku Evropské aliance pro společenskou odpovědnost podniků: „Partnerství, které dnes vzniklo, je otevřenou aliancí, jejímž cílem je dodat nové podněty iniciativám v oblasti společenské odpovědnosti podnikù. Věř́m, že společenská odpovědnost podniků může pracujicím pomoci při lepši adaptaci na změny a při získáváni kvalifikace potřebné pro hospodářství $v 21$. století. Může rovněž přispět $k$ tomu, aby se realitou $v$ evropských společnostech stalo vytváření rovných př́ležitostí, a podpořit integraci znevýhodněných skupin. “"

Vrátím-li se ale $\mathrm{k}$ materiálu označovanému jako Nový průvodce, zjišt'uji při bližším přihlédnutí, že oblast sociální integrace není dále podrobněji rozpracována. V kapitole, která se týká měřitelnosti, nejsou již dopady na komunitu a speciálně sociální integrace zmiňovány

\footnotetext{
${ }^{3}$ Vycházím ze základních materiálů vzniklých v ČR „Nový průvodce CSR“, uveřejněný na http://www.csronline.cz/Page.aspx?pruvodce a z publikace citované na str. 1 .

${ }^{4}$ Citace převzata z http://neziskovky.cz/cz/neziskovky-cz/csr/aktuality/2617.html
} 
a podobné je to i v dalších kapitolách. V dotazníku pro firmy nejsou otázky, které by dokázaly indikovat zapojení marginalizovaných skupin do činnosti podniku, v př́kladech činností a jejich indikátorů není sociální integrace rovněž zmíněná. Podíváme-li se znovu do materiálu „SPOLEČENSKÁ ODPOVĚDNOST FIREM kompletní průvodce tématem a závěry výzkumu v ČR“ z roku 2004 zjišt’ujeme následující: V sociální oblasti patří do rámce CSR rovné př́ležitosti a to nejen žen a mužů, ale také rovné př́ležitosti dalších znevýhodněných skupin. V další části se ale ihned dodává, že v prostředí ČR je pojem rovných př́ležitostí redukován pouze na rovné př́ležitosti žen a mužů, zatímco ve světě zahrnuje také rovné př́ležitosti pro etnické minority, zdravotně handicapované a seniory. Přitom je zřejmé, že rovné př́ležitosti pro národnostní menšiny a lidi sociálně a zdravotně znevýhodněné jsou právě tím stěžejním předpokladem pro sociální integraci těchto lidí v podnikatelském prostředí. Podobně hovoří také výzkumná část tohoto materiálu. Mezi tématy, která považují firmy za důležitá v rámci CSR, se rovné příležitosti pro znevýhodněné skupiny nevyskytují.

Mohu-li trochu odbočit, dodávám, že za velmi důležité považují zástupci podniků všech velikostí dárcovství či nadační činnost. Uvedu př́klad: Petr Hlínka uvádí ve své prezentaci společenské odpovědnosti ČSOB jako př́ípad sociální integrace podporu Člověka v Tísni v jeho sociálních programech v Ústí n. Labem, Kladně a Plzni.

Toto je ale prrípad donátorství, které má jistě velmi pozitivní dopad, ale není tím integračním mechanismem, o který mi nyní jde. Jedná se jistě o rozšířenou formu realizace společenské odpovědnosti firem či naplňování jejího sociálního pilíre, ale tato forma byt' je nesmírně př́nosná pro sféru dlouhodobě podfinacovaných neziskových organizací a zejména pro samotnou cílovou skupinu lidí sociálně vyloučených, není tak intenzivním lékem na segregaci, jakým může být společenská odpovědnost vyjádřená zapojením segregovaných skupin do činnosti firem.

Mám-li shrnout výše uvedené, musím na jedné straně konstatovat, že stát nevytváří doposud ideální podmínky pro uplatnění společenské odpovědnosti firem v oblasti sociální integrace a v souladu s tím nevidí firmy prozatím sociální integraci jako prostor, kde by měly CSR plnohodnotně uplatňovat. Vrátím-li se na okamžik $\mathrm{k}$ dokumentu Nový průvodce ..., odůvodňuje se $\mathrm{v}$ něm, proč je $\mathrm{v}$ rámci sociálního pilíre třeba hovořit odděleně o pracovním prostředí uvnitř firmy a starostí o komunitu. Možná právě toto dělení na vnitřní a vnější hledisko je výrazem skutečnosti, že v našich očích jsou prosperita, úspěšnost firmy, zisk na jedné straně a pomoc znevýhodněným na druhé straně dvě různé věci. Propojené charakterem majitelů společnosti, nikoli však spojené do jednoho procesu. Stává-li se CSR postupně na trajektorii od mezinárodních korporací po malé podniky regionálního charakteru mainstreamovou záležitostí, neplatí to jistě o sociální integraci jako jedné z typických aktivit, prostřednictvím které se CSR uplatňuje.

\section{Př́íklad dobré praxe}

Samozřejmě, že existuje celá řada př́padů, kdy firmy využívají stávajících legislativních a dotačních podmínek $\mathrm{k}$ podpoře sociální integrace. Jako př́klady dobré praxe mohu uvést např́íklad projekt spolupráce technických služeb v Hranicích na Moravě s firmou Sterena. Projekt je osvědčen a běží již řadu let. Nejedná se však pouze o nápad, který se bude či nebude realizovat, nýbrž o hotový investiční záměr.

V roce 2003 vznikla aktuální potřeba řešit problematiku zaměstnávání problémových a těžko uplatnitelných skupin obyvatel ve městě Hranicích, se zvláštním zřetelem na dlouhodobě 
nezaměstnané. Jako možný zaměstnavatel byl městem vybrán podnik EKOLTES Hranice, a.s., jejímž stoprocentním vlastníkem je město Hranice. Jedná se vlastně o technické služby města. Podnik provozuje činnosti, ve kterých se mohou méně kvalifikovaní pracovníci, bez větších požadavků na zaškolení, uplatnit. Jedná se zejména o úklid veřejných prostor a objektů; péče o veřejnou zeleň, běžná údržba nemovitostí, svoz a likvidace komunálního odpadu apod. Již na začátku projektu bylo stanoveno, že Ekoltes bude outsorcovat výše uvedené služby a to formou speciální spolupráce s firmou, která se specializuje na lidi obtížně uplatnitelné na trhu práce., s firmou Sterena s.r.o, kterou vlastní p. Danis.

Cílem tohoto projektu bylo:

1. Vybranou skupinu naučit základním pracovním návykem (denní př́ichod do zaměstnání, plnění pracovních povinností, dodržování organizace práce, potřebné kvality provedených prací apod.).

2. Po zapracování $\mathrm{v}$ jednoduchých pracovních činnostech vytipovat ty nejschopnější a umožnit jim rekvalifikaci na vyšší formu práce (křovinořez, motorová pila, motorová sekačka až třeba po řidičský průkaz nebo rekvalifikační kurz dlaždič, zedník).

3. Po prověření pracovních kvalit uvolnit tyto pracovníky pro normální trh práce $s$ doporučením a.s., města Hranic a ÚP pro eventuální zaměstnavatele nebo pomoci při získání Živnostenského listu pro soukromé podnikání.

Projekt byl zahájen k datu 1. 4. 2005. První rok byla mzdová oblast firmy Sterena dotovaná ve spolupráci s ÚP z politiky aktivní zaměstnanosti.

Od 1.6. 2006 probíhá projekt na čistě obchodní bázi bez jakýchkoli dotací ze strany státu, kraje či města. Firma Sterena i podnik Ekoltes jsou ve městě dobře známé svojí spolehlivostí a precizností odváděné práce. O principech společenské odpovědnosti zde mohu hovořit $\mathrm{v}$ př́padě obou spolupracujících subjektů. Firma Ekoltes subkontrahuje část svých zakázek firmě Sterena. Přebírá tak odpovědnost za dodávky firmy, která zaměstnává sociálně znevýhodněné a zř́ká se tak části př́ípadného zisku. $\mathrm{Na}$ druhou stranu převádí část nekvalifikované práce na firmu, která se na ni specializuje a může se soustředit na jiný typ zakázek. Ekonomická výhodnost je tu propojena s jasným komunitním či sociálním zřetelem. Efektivitu tohoto spojení dokazuje úspěšnost firmy. Lze namítnout, že tato společnost je vlastněná městem, je zrrízená pro plnění jeho zakázek, alespoň částečně, a reaguje tak na společenskou objednávku obce. Tato námitka pro mě ale není přiměřená v situaci, kdy většina měst tuto zakázku, rozuměj zaměstnávání relevantního počtu těžko uplatnitelných pracovníků, nedává a celá řada obdobných společností takové zakázky nepřijímá.

Krystalicky jasná je však společenská odpovědnost v př́ipadě firmy Sterena s.r.o., která jako část pracovníků přijímá lidi, kteří jsou znevýhodnění na trhu práce, část těchto pracovníků přitom připravuje ne pro rozvoj svoji činnosti, ale pro jejich další uplatnění na trhu práce. Velmi zajímavé je, že dotaci Úřadu práce, která je určená pro lidi dlouhodobě nezaměstnané využívá pro lidi, u nichž se kumulují další znevýhodnění, příslušnost k jiné než většinové etnicitě, zadluženost, sociálně pat. jevy. Začlenění těchto lidí do aktivit firmy lze jednoznačně chápat jako výrazný počin sociální integrace.

Prospěch, který tím firma na druhou stranu získává, spočívá v trvalosti smluvního vztahu s firmou Ekoltes, velmi úzký vztah s městem a Úřadem práce. Nahrazuje tak nepochybně zisk maximální, ziskem optimálním, zisk př́ležitostný ziskem relativně stabilním a dlouhodobým. Otázka měřitelnosti společenské odpovědnosti má $\mathrm{v}$ tomto př́padě několik rovin. $\mathrm{V}$ prvním plánu mohu jednoduše, podobně jako $\mathrm{v}$ jazyce projektu, mluvit o počtu takto podpořených 
osob. Subtilněji však mohu sledovat sociální začlenění těchto lidí např. jejich udržením pracovně právního vztahu, dalším uplatněním na trhu práce, stabilizací jejich finančních poměrů, podmínek pro bydlení apod. Úspěšnost tohoto projevu odpovědného chování firmy lze měřit také z pozice města - snížení sociálně patologických jevů, z pohledu státní správy úbytkem nákladů na vyplácení dávek $\mathrm{v}$ hmotné nouzi, $\mathrm{z}$ pohledu Úřadu práce $\mathrm{v}$ úbytku dlouhodobě nezaměstnaných.

\section{Marketingový výzkum}

Průzkum byl proveden v roce 2011 v rámci projektu ,Sociální podnikání jako způsob myšlení a tvořivosti“, reg. číslo CZ.1.07/2.2.00/07.0045, a měl dvě etapy, kdy v první etapě bylo osloveno 100 náhodně vybraných respondentů z MS kraje a ve druhé pak 50 společností MS kraje, zabývající se sociálním podnikáním.

V první etapě jsem analýzou odpovědí došla k následujícím závěrům:

a) Z dotazníkového šetření nám vyplynulo, že dosažený stupeň vzdělání má vliv na informovanost respondentů ohledně problematiky Společenské odpovědnosti firem (soc. podnikání, atd.)

b) Respondenti ze severní Moravy, vysokoškolsky vzdělaní 44\%, středoškoláci $32 \%$, zbytek dotazovaných s nižším vzděláním než je SŠ (ZŠ, učiliště) $24 \%$, odpověděli, že informace o společensky odpovědném chování firem má vliv jejich na rozhodování zákazníků o koupi daného produktu, tj. respondenti jsou ochotni si připlatit za výrobek od firem, které se chovají společensky odpovědně.

Graf č. 1: chápání pojmu společenská odpovědnost firem mezi českou veřejností

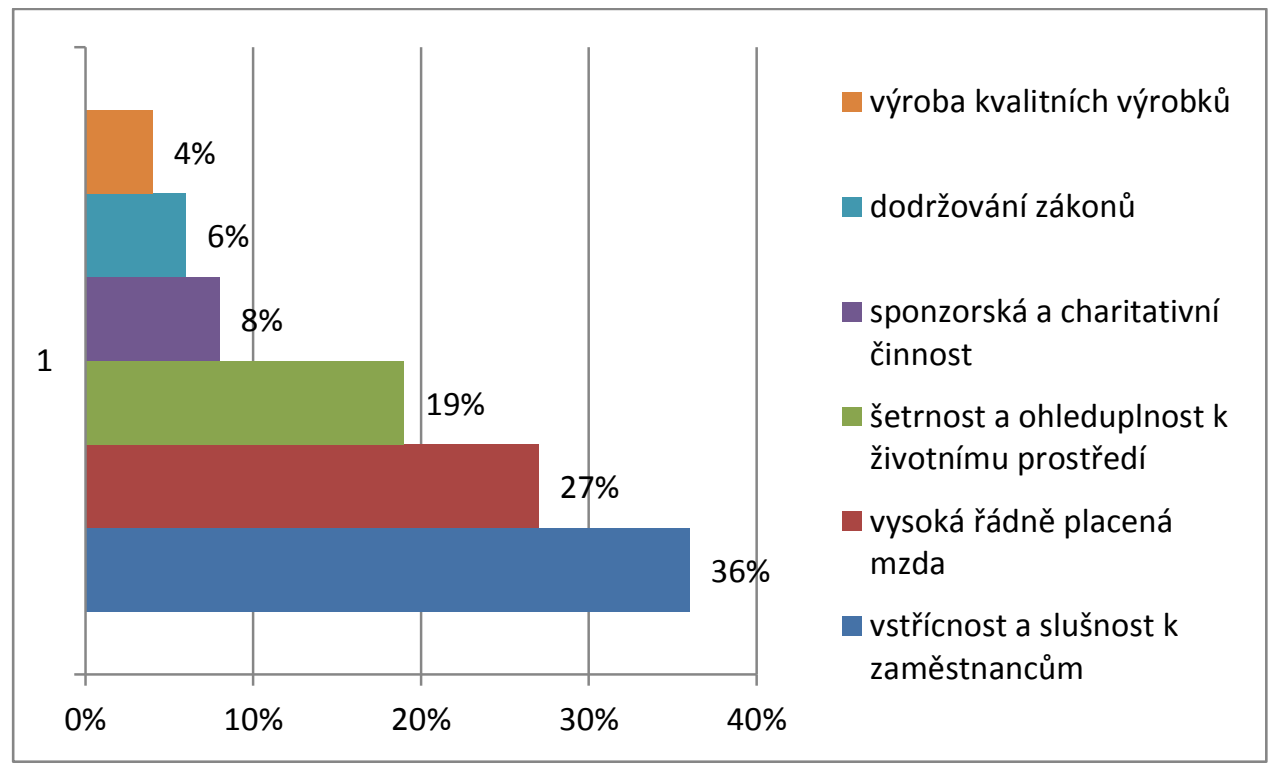

Pramen: autor př́spěvku

Komentář ke grafu č.1: graf nám ilustruje chápání pojmu společenská odpovědnost firem mezi českou veřejností tj. dotaz zněl, $v$ jakých činnostech by se měla firma angažovat, aby byla společensky zodpovědná. 
c) Další otázka zjišt'ovala názory na to, zda by velké firmy měly pomáhat vládě řešit sociální problémy státu:

Tři čtvrtiny (74\%) respondentů jsou přesvědčeny, že by se velké společnosti měly spolupodílet na řešení sociálních problémů země. Pouze každý sedmý zastává opačný názor. Desetina dotázaných neví.

Zjištěných $74 \%$ kladných odpovědí významně koresponduje s výsledky celoevropského průzkumu, v němž 64 \% Evropanů konstatovalo, že velké společnosti musejí pomoci vládám řešit sociální problémy.

Co se týká II. etapy dotazníkové šetření mezi firmami, zabývajícími se sociálním podnikáním (tzn. že jejich podnikatelské aktivity prospívají společnosti či životnímu prostředí), analýzou odpovědí jsme došli mj. k následujícím závěrům:

a) Graf číslo 2 nám znázorňuje aktivity českých firem v sociální rovině společenské odpovědnosti firem v následujících oblastech:

- rozvoj lidského kapitálu, vzdělávání zaměstnanců

- zdraví a bezpečnost zaměstnanců

- rovné př́ležitosti (pro ženy, muže a obecně znevýhodněné skupiny)

- rozmanitost na pracovišti (etnické minority, handicapovaní a starší lidé)

- zajištění rekvalifikace propouštěných zaměstnanců pro jejich další uplatnění

- dodržování pracovních standardů, zákaz dětské práce

- firemní filantropie (dárcovství, firemní dobrovolnictví a další)

Graf č.2: aktivity českých firem v oblasti společenské odpovědnosti

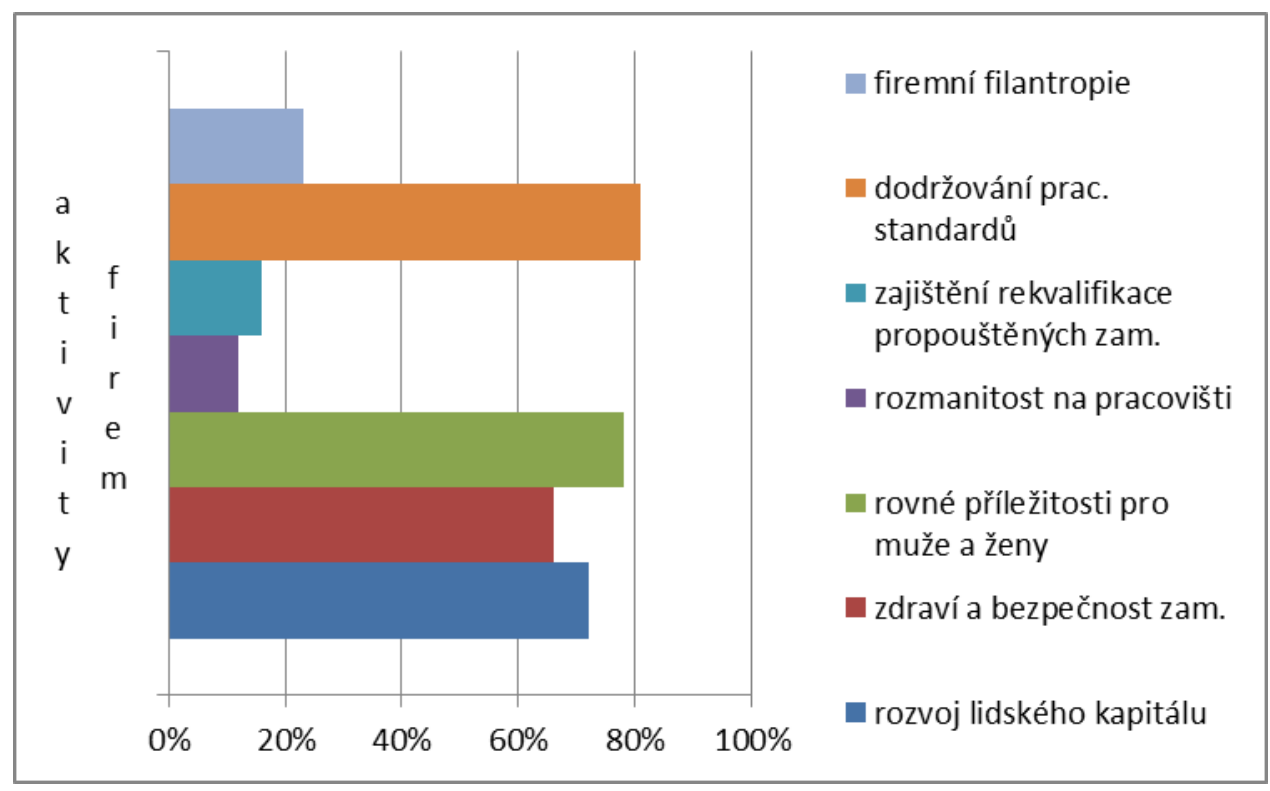

Pramen: autor př́spěvku

Komentář ke grafu č.2: graf číslo 2 nám znázorňuje \% firem z padesáti oslovených, angažujících se voblasti, týkající se např. péče o zaměstnance, spolupráce se školami, ekologické oblasti atd. 
Co se týká aktivit firem $\mathrm{v}$ oblasti soc. integrace, potvrzuje se nám to, že pouze mizivé procento se angažuje $\mathrm{v}$ této oblasti.

Co se týká celkového vyhodnocení výsledků dotazníkového šetření v rámci projektu „Sociální podnikání jako způsob myšlení a tvořivost", které jsem realizovala, analýza odpovědí potvrzuje to, že sociální podnikání se firmám vyplácí, veřejnost vnímá stále intenzivněji společensky odpovědné chování firem a spotřebitelé jsou dokonce ochotni si připlatit za výrobek od těchto firem.

Velmi zajímavé jsou pak výsledky dotazníkového šetření, týkající se chápání pojmu společenská odpovědnost firem mezi veřejností v Moravskoslezském kraji, znázorňující graf č. 1. Dále pak procentuální grafické znázornění aktivit českých firem v sociální rovině, viz. graf číslo 2. Analýza odpovědí dotazníkového šetření nám dále pak potvrzuje i to, že skutečně jen mizivé procento firem směřuje své aktivity do oblasti sociální integrace.

\section{Závěr}

V první části článku jsem se pokusila vystihnout, do jaké míry stát vytváří podmínky pro to, aby se společenská odpovědnost firem uplatňovala v oblasti sociální integrace a nakolik je $\mathrm{v}$ našem prostředí tento koncept $\mathrm{s}$ danou problematikou spojován. Uvedený př́klad ve druhé části ukazuje, že i za využití stávajících dotačních pobídek je možné odpovědnost firem na poli sociální integrace uplatňovat. Domnívám se, že zapojování znevýhodněných skupin obyvatel do činnosti podniků, či chcete-li vytváření rovných př́ležitostí pro tyto skupiny, je jednou z kmenových činností, v nichž se společenská odpovědnost může uplatňovat a že se nedostatkem aktivity na tomto poli odlišujeme od vyspělých demokracií. A to že jen mizivé procento firem směřuje své aktivity do oblasti sociální integrace bylo rovněž potvrzeno provedeným výzkumem, jehož výsledky jsem prezentovala v tomto článku. Kdy narozdíl od jiných oblastí lze odpovědnost na poli sociálního začleňování velmi zřetelně indikovat či měřit. Ráda bych touto cestou alespoň trochu přispěla $\mathrm{k}$ tomu, aby se sociální začleňování stalo předmětem zájmu odborníků na koncept společenské odpovědnosti a jejich prostřednictvím také samotných podnikatelů. Jsem přesvědčená, že neplatí jednosměrně „tam, kde stát vytváŕí odpovídající podmínky, tam teprve vzniká prostor pro uplatňování odpovědnosti“", ale také opačně (jedná se o interaktivní proces): „tam, kde se rozvíjí aktivity společenské odpovědnosti, vzniká tlak na stát, aby rozšiřoval možnosti pro její podporu.“

\section{Literatura:}

[1] BLAŽEK, L., Doležalová, K., Klapalová, A., Společenská odpovědnost podniků, Working Paper č. 9/2005, Centrum výzkumu konkurenční schopnosti české ekonomiky, 2005, 60 s. ISSN 1801-4496

[2] CS EUROPE: Enterprise 2020, [online]. Belgie: CS EUROPE, Evropská obchodní sít' pro sociální odpovédnost podniků. Dostupné na: http://www.csreurope.org/pages/en/enterprise2020.html

[3] DOHNAlovÁ, M., DEVEROVÁ, L., PETRlíKOVÁ, B., SVPBODA, J. Sociální ekonomika a sociální podnikání. Brno: Akademické nakladatelství CERM, 2007, ISBN 978-80-7204-552-5.

[4] IISD: Obchod a udržitelný rozvoj, [online]. Kanada: IISD, Mezinárodní institut pro udržitelný rozvoj. Dostupné na:

http://www.iisd.org/business/issues/eu_green_paper.aspx 
[5] KALOUSOVÁ, P. Od filantropie k odpovědnosti. CSR fórum. Časopis o společenské odpovědnosti firem. 2010, roč. 4, č. 6, s 8-9.

[6] Kolektiv autorů. Napřič společenskou odpovědností firem. 1.vyd. Kladno: Aisis, 2005. 163 s. ISBN 80-239-6111-X.

[7] PAVLÍK, M., BĚLČÍK, M. Společenská odpovědnost organizací-CSR v praxi a jak s ním dál. 1. vyd. Praha: Grada, 2010. 169 s. ISBN 978-80-247-3157-5.

[8] PETříKOVÁ, R. Společenská odpovédnost organizací. 1. vyd. Ostrava: DTO CZ, 2008. 184 s. ISBN 978-80-02-02099-8.

[9] SILBERHORN, D., Warren, R. C. (2007). Defining corporate social responsibility. A view from big companies in Germany and the UK. European Business Review. Vol. 19, No. 5, pp. 352-372.

[10] TRNKOVÁ J., Společenská odpovědnost firem(Corporate Social Responsibility)kompletní průvodce tématem \& závěry z průzkumu v ČR. 2004, BUSINESS LEADERS FORUM, dostupné na http://www.blf.cz/csr/cz/vyzkum.pdf

\section{JEL A13}

\section{Ing. Renáta Nárožná}

Interní doktorand Katedra ekonomie

Obchodně podnikatelská fakulta v Karviné

Slezská univerzita v Opavě

Univerzitní náměstí 1934/3, 73340 Karviná

Tel.: 775554477

r.pcz@ seznam.cz 